\title{
Influence of pre-sowing treatments by gamma rays on growth, yield and some chemical constituents of Sesamum indicum L.
}

\author{
O.S. Hussein ${ }^{\bowtie}$ and N. Hamideldin \\ Natural Products Department, National Center for Radiation Research and Technology, \\ Atomic Energy Authority, P.O. box 29, Nasr City, Cairo \\ ${ }^{\square}$ Corresponding author: Omyma.S.Hussein@eaea.org.eg
}

Submitted: 23 March 2015; Accepted: 29 June 2015

SUMMARY: The present work aims to improve the quantity and quality of seeds and/or seed oil by using low doses of radiation. Sesame seeds were exposed to $\gamma$ - rays at levels of 30,60 and $90 \mathrm{~Gy}$. The results show that 30, 60 and 90 Gy doses activated most of growth and yield parameters significantly (weight of plant, number of capsules, weight of capsules/plant and weight of seeds/plant), with $60 \mathrm{~Gy}$ being the best dose. With regard to the total oil percentage in the produced crops, few changes have been observed, which did not reach the level of significance. The amount of unsaturated fatty acid (18:1, omega 9) was increase by $10.5 \%$ at a 30 Gy dose followed by $60 \mathrm{~Gy}(1.1 \%)$. The total of amino acid content showed that $30 \mathrm{~Gy}$ dose recorded the highest value $\left(350.4 \mathrm{mg} \cdot \mathrm{g}^{-1}\right)$ followed by $60 \mathrm{~Gy}\left(285.6 \mathrm{mg} \cdot \mathrm{g}^{-1}\right)$ as compared to the control value $\left(254.4 \mathrm{mg} \cdot \mathrm{g}^{-1}\right)$. The values of phosphorus, potassium magnesium and iron which represent the major minerals in sesame seeds were increased in the irradiated samples.

KEYWORDS: Amino acids; Fatty acid; $\gamma$-rays; Minerals; Oil content; Sesame

RESUMEN: Influencia de tratamientos con rayos gamma en la presiembra sobre el crecimiento, rendimiento y algunos componentes químicos de Sesamum indicum $L$. El presente trabajo tiene como objetivo mejorar la cantidad y la calidad de las semillas y/o aceite de semillas mediante el uso de dosis bajas de radiación. Las semillas de sésamo se expusieron a rayos $\gamma$ - a niveles de 30, 60 y 90 Gy. Los resultados mostraron que las dosis de 30, 60 y 90 Gy activan significativamente la mayor parte de los parámetros de crecimiento y rendimiento (peso de la planta, número de cápsulas, peso de cápsulas/planta y el peso de semillas/planta), siendo 60 Gy la mejor dosis. Con respecto al porcentaje total de aceite producido en los cultivos, se han observado pequeños cambios, pero no se alcanzó el nivel de significación. La cantidad de ácido graso insaturado (18: 1, omega 9) fue 10,5\% que aumentó con dosis de 30 Gy seguido de 60 Gy $(1,1 \%)$. El contenido total de aminoácidos mostró que dosis de 30 Gy registró el valor más alto $\left(350,4 \mathrm{mg} \cdot \mathrm{g}^{-1}\right)$, seguido de $60 \mathrm{~Gy}\left(285.6 \mathrm{mg} \cdot \mathrm{g}^{-1}\right)$, en comparación con el valor de control $\left(254,4 \mathrm{mg} \cdot \mathrm{g}^{-1}\right)$. Los valores de fósforo, magnesio, potasio y hierro, que son los principales minerales en las semillas de sésamo incrementaron en las muestras irradiadas.

PALABRAS CLAVE: Ácidos grasos; Aminoácidos; Contenido de aceite; Minerales; Rayos $\gamma$; Sésamo

Citation/Cómo citar este artículo: Hussein OS, Hamideldin N. 2015. Influence of pre-sowing treatments by gamma rays on growth, yield and some chemical constituents of Sesamum indicum L. Grasas Aceites 67 (1): e111. doi: http:// dx.doi.org/10.3989/gya.0374151.

Copyright: (C) 2016 CSIC. This is an open-access article distributed under the terms of the Creative Commons Attribution-Non Commercial (by-nc) Spain 3.0 Licence. 


\section{INTRODUCTION}

Sesamum indicum L. crop is grown as a source of oil; its seeds contain $50-52 \%$ oil, $17-19 \%$ protein and 16-18\% carbohydrates (Ustimenko-Bakumovsky, 1980). It is considered a good source of oil which has very good stability due to the presence of natural antioxidants (Ashri, 2007). It belongs to the category of most nutritious seeds and is used as a culinary spice. Sesamum produces unique chemical constituents which do not exist in other edible oils. These chemical constituents enable sesame oil to resist oxidative rancidity and thus contribute to its reputation of high quality, earning the sesame label "Queen of Oil seed crops" (Al-Yemeni et al., 2000; Bedigian, 2000). Sesame is used in the treatment of anemia, blurred vision and relaxation of the bowel. Seed irradiation during the pre-sowing processes is one of the most effective methods for improving plant production, yield components and chemical composition (Rahimi and Bahrani, 2011). Although gamma radiation is a technology with immense applications in agriculture, industry and medicine, its potential exploitation in agriculture is limited because of a lack of information on the optimal dose of irradiation, which differs from one crop to another and from one application to another. Radiation mediated morphological, structural and/or functional changes in a plant which are governed by the intensity and duration of exposure to gamma rays (Singh and Datta, 2010). Gamma rays have been reported to differentially affect the morphology; anatomy, biochemistry, and physiology of a plant, depending on the irradiation level (Kim et al., 2004; Wi et al., 2005). These effects include changes in plant cellular structure and metabolism, e.g. dilution of thylakoid membranes, alteration in photosynthesis, modulation of antioxidant system, and accumulation of phenolic compounds. This work was carried out to investigate the response of sesame seeds (Sesamum indicum L.) to low doses of gamma rays for improving plant growth, yield and oil quality.

\section{MATERIAL AND METHODS}

Sesamum indicum L. shandweel-3 cultivar seeds were obtained from the Agricultural Research Center, Giza, Egypt. The sesame seeds were irradiated at levels of 30,60 and $90 \mathrm{~Gy}$ in gamma cells using $\mathrm{Co}^{60}$ as a source for radiation, in the National Center for Radiation Research and Technology (NCRRT), Cairo, Egypt. The dose rate was $0.48 \mathrm{~Gy} \mathrm{~min}^{-1}$.

\subsection{Experimental design}

The sesame seeds exposed to gamma rays before sowing were sown together with control seeds in sandy-loam soils in completely randomized blocks with three replicates under a screened house. The soil was fertilized according to the recommendations of the Egyptian Ministry of Agriculture and Land Reclamation (150 kg calcium super phosphate, $100 \mathrm{~kg}$ potassium sulphate and $100 \mathrm{~kg}$ ammonium sulphate) at the beginning of the experiment. At harvest time, the plants were collected and cleaned for recording growth, yield and other physiological parameters.

\subsection{Growth and Yield Parameters}

Ten plants were chosen and length of shoot $(\mathrm{cm})$, stem diameter (cm), number of capsule (unit/plant) and length of capsule $(\mathrm{cm})$, weight of capsule per plant $(\mathrm{g})$, and weight of seeds per plant $(\mathrm{g})$ were recorded. Also, the changes in physicochemical properties were estimated.

\subsection{Physicochemical parameters}

\subsubsection{Moisture content}

Moisture content was determined according to the AACC (1993).

\subsubsection{Oil viscosity}

Viscosity measurements were carried out using a BrookfiledReology RV model DV-III, Viscometer which is computerized and programmable as controlled by Rheocalc (1.3 versions). An oil samples $(8-16 \mathrm{~mL})$ from sesame obtained from irradiated or unirradiated seeds was placed in sample adaptor cup and maintained at $25^{\circ} \mathrm{C}$ using the Brookfield TC500 unit. The spindle used was a SC4-21 and applied within the up and down program (from 25 up to $250 \mathrm{rpm}$ ) and then reduced to $25 \mathrm{rpm}$ with a 30 second interval between each speed rotation. The other speeds used were 50, 75 and $100 \mathrm{rpm}$; the viscosity $\mathrm{cP}$ was automatically calculated by the Rheocalc program software.

\subsubsection{Total oil percentages}

The total oil content of each treatment was extracted by weighing 10-15 g of sesame seed powder placed in soxhlet apparatus with hexane for about 16 hours. An empty, clean, dry, round flask was weighed before and after extraction. Solvents were evaporated and oil percentage was calculated (AOAC, 1984).

\subsubsection{Estimation of fatty acids}

The separation of fatty acid methyl esters from oil samples was prepared according to protocol 31 of the extraction of lipids and derivative formation (Hamilton et al., 1992). Five $\mathrm{mL}$ of the sulphuric acid:methanol:toluene reagent were added to $50 \mathrm{mg}$ 
of lipids in a screw cap vial and heated in a water bath for $60 \mathrm{~min}$. Five $\mathrm{mL}$ of water and $5 \mathrm{~mL}$ of diethyl ether were added and the mixture was shaken before removing the lower layer. The upper layer was decanted onto anhydrous sodium sulphate. The samples were analyzed at NCRRT with a Hewlet Packard gas chromatograph with a flam ionization detector. The gas chromatograph instrument was equipped with an hp 6890 innowax- cross linked polyethylene glycol column $30 \mathrm{~m}$; i.d. $0.32 \mathrm{~mm} ; 0.5 \mathrm{~m}$ film thickness. The oven temperature was programmed from $150{ }^{\circ} \mathrm{C}$ to $450{ }^{\circ} \mathrm{C}$ for five minutes; the injector and detector were kept at $260^{\circ} \mathrm{C}$ and $275^{\circ} \mathrm{C}$, respectively. Nitrogen was used as carrier gas at a flow rate of $1.5 \mathrm{~min}^{-1}$.

\subsubsection{Mineral Content}

Minerals were measured in sesame powder at NCRRT on an Energy Dispersive X-Ray-Analysis Model: (Oxford) attached to a scanning electron microscope (JEOL-JSM 5400). The analysis depends on the X-ray radiation emitted from each element, where the specimen was bombarded with high energetic electrons used to determine the kind of the elements that exist in the specimen surface and their percentages. The elements estimated were calcium, chlorine, iron, potassium, magnesium, sodium and phosphorus.

\subsubsection{Amino Acids}

The amino acids analysis was done in an amino acids laboratory, NCRRT after sample preparation by weighing $(100 \mathrm{mg})$ dried sesame seed powder in screw-capped glass tubes containing $10 \mathrm{~mL}$ of $6.0 \mathrm{~N}$ $\mathrm{HCl}$, kept in an oven at $110{ }^{\circ} \mathrm{C}$ for 24 hours for complete digestion (AOAC, 1990). The sample was filtered and the volume was completed to $100 \mathrm{~mL}$ with distilled water. Five $\mathrm{mL}$ of the solution were evaporated to dryness. A suitable volume of sodium citrate buffer ( $\mathrm{pH}$ 2.2) was added to the dried film of each hydrolyzed sample. After all materials had completely dissolved, the samples were filtered through a 0.4 um membrane filter and made ready for injection (Baxter, 1996). The system used for analysis was the high performance amino acid analyzer, Biochroma 20 Pharmacia Biotech at NCRRT. Data analysis of the chromatogram was done by Chromatography Data System Tutorial and user's Guide, version 6.7.

\subsection{Statistical analysis}

The data obtained were analyzed statistically using the Costat statistical program software, 1990 and Duncan's multiple range according to Duncan (1955).

\section{RESULTS}

\subsection{Growth and yield characteristics}

The data in Table 1 show a significant increase in the growth and yield parameters of sesame plants resulting from seeds exposed to $\gamma$ - rays at levels of 30, 60 and 90 Gy before sowing. It was noticed that dose 60 Gy was more effective for weight of plant, number of capsules, weight of capsules/plant and weight of seeds/plant to register the greatest improvement. Gamma rays may cause changes in shoot morphological characteristics at the level of 30,60 or 90 and Gy affected the stem diameter. Stem diameter increased significantly by $46.9 \%$ in the 30 Gy treatment and increased by $71.9 \%$ in both the 60 and 90 Gy treatments.

\subsection{Oil Percentage and oil characteristics}

The data showed that moisture content and oil contents were increased in the $30 \mathrm{~Gy}$ dose of gamma rays irradiated population followed by 60 and $90 \mathrm{~Gy}$ (Table 2). Moisture and oil contents increased in the seeds produced from 30 Gy samples followed by $60 \mathrm{~Gy}$. The amount of unsaturated fatty acids (Oleic $18: 1$, omega 9) was increased by $10.5 \%$ at $30 \mathrm{~Gy}$ followed by the 60 Gy dose which increased by $1.1 \%$, while a slight increase $(0.45 \%)$ in fatty acids (linoleic 18:2, omega 6) at dose 90 Gy was observed. Omega 6 and omega 9 are antioxidant components. Furthermore, doses of $\gamma$ - rays 30 or 60 Gy caused a great drop in oil viscosity, although dose 90 Gy increased it significantly.

\subsection{Mineral content}

It is evident from Table 3 that $\mathrm{K}$ and $\mathrm{P}$ are the main constituents in the ash of sesame seeds. The contents of $\mathrm{K}$ were especially high in comparison to $\mathrm{Na}$ which is considered to be an advantage from the nutritional point of view. However, a large variation in the $\mathrm{Ca}$ content has been reported. It was noticed that the control value of $27.2 \mathrm{~g} \cdot \mathrm{kg}^{-1}$ decreased to $24.4 \mathrm{~g} \cdot \mathrm{kg}^{-1}$ in the $60 \mathrm{~Gy}$ treatment and $17.7 \mathrm{~g} \cdot \mathrm{kg}^{-1}$ in the 30 Gy treatment. Magnesium represents the fourth major element found in sesame seeds after $P$, $\mathrm{K}$ and $\mathrm{Ca}$. Magnesium was significantly improved in the irradiated sample. Iron was present in a low amount in the untreated sample $(0.96 \%)$, while it was increased by $202 \%, 56.3 \%$ and $35.4 \%$ in 30,60 and 90 Gy treatments, respectively.

\subsection{Amino acids}

All values of amino acids were separated in the profiles of the samples treated with 30 , and 60 Gy and all amino acids, except proline, were increased above the control value. The results (Table 4) revealed that 
TABLE 1. Effect of pre-sowing irradiation treatments on sesame growth and yield parameters

\begin{tabular}{lccccccc}
\hline Dose (Gy) & $\begin{array}{c}\text { Plant } \\
\text { height (cm) }\end{array}$ & $\begin{array}{c}\text { Stem } \\
\text { diameter (cm) }\end{array}$ & $\begin{array}{c}\text { Plant } \\
\text { weight (g) }\end{array}$ & $\begin{array}{c}\text { Capsule } \\
\text { length (cm) }\end{array}$ & $\begin{array}{c}\text { Capsule } \\
\text { number/plant }\end{array}$ & $\begin{array}{c}\text { Capsules } \\
\text { weight/plant (g) }\end{array}$ & $\begin{array}{c}\text { Seeds } \\
\text { weight/plant (g) }\end{array}$ \\
\hline 0.0 & $146.2^{\mathrm{a}}$ & $0.64^{\mathrm{c}}$ & $26.2^{\mathrm{b}}$ & $3.7^{\mathrm{a}}$ & $39.4^{\mathrm{c}}$ & $18.5^{\mathrm{b}}$ & $13.0^{\mathrm{c}}$ \\
30 & $147.4^{\mathrm{a}}$ & $0.94^{\mathrm{b}}$ & $48.6^{\mathrm{a}}$ & $4.0^{\mathrm{a}}$ & $80.8^{\mathrm{ab}}$ & $34.8^{\mathrm{a}}$ & $18.0^{\mathrm{b}}$ \\
60 & $154.0^{\mathrm{a}}$ & $1.1^{\mathrm{a}}$ & $58.7^{\mathrm{a}}$ & $4.2^{\mathrm{a}}$ & $101.8^{\mathrm{a}}$ & $39.5^{\mathrm{a}}$ & $27.0^{\mathrm{a}}$ \\
90 & $162.4^{\mathrm{a}}$ & $1.1^{\mathrm{a}}$ & $59.6^{\mathrm{a}}$ & $4.1^{\mathrm{a}}$ & $64.2^{\mathrm{b}}$ & $39.4^{\mathrm{a}}$ & $19.0^{\mathrm{b}}$ \\
\hline
\end{tabular}

The control (0.0) represents untreated plants. The other groups of plants were irradiated with different doses of $\gamma$-rays. Each value is the mean of ten replicates. Different letters indicate significant variation.

TABLE 2. Effect of pre-sowing irradiation treatments on moisture content, oil content, oil viscosity and major fatty acids

\begin{tabular}{|c|c|c|c|c|c|c|c|c|c|c|}
\hline \multirow[b]{2}{*}{ Dose Gy } & \multirow[b]{2}{*}{ Moisture \% } & \multirow[b]{2}{*}{ Oil \% } & \multicolumn{4}{|c|}{ Oil Viscosity cP } & \multicolumn{4}{|c|}{ Fatty acids } \\
\hline & & & 25 & 50 & 75 & 100 & $16: 0$ & 18:0 & 18:1 & $18: 2$ \\
\hline 0.0 & $3.1^{\mathrm{a}}$ & $49.7^{\mathrm{a}}$ & $36^{\mathrm{b}}$ & $33.3^{\mathrm{a}}$ & $33.0^{\mathrm{a}}$ & $33.0^{\mathrm{a}}$ & 10.9 & 3.9 & 44.9 & 44.3 \\
\hline 30 & $3.8^{\mathrm{a}}$ & $62.4^{\mathrm{a}}$ & $30^{\mathrm{c}}$ & $17.0^{\mathrm{b}}$ & $16.0^{\mathrm{b}}$ & $15.0^{\mathrm{b}}$ & 11.0 & 3.9 & 49.6 & 35.5 \\
\hline 60 & $3.2^{\mathrm{a}}$ & $58.6^{\mathrm{a}}$ & $22^{\mathrm{d}}$ & $19.0^{\mathrm{b}}$ & $18.8^{\mathrm{b}}$ & $18.5^{\mathrm{b}}$ & 8.4 & 2.8 & 45.4 & 43.4 \\
\hline 90 & $3.2^{\mathrm{a}}$ & $55.7^{\mathrm{a}}$ & $40^{\mathrm{a}}$ & $35.0^{\mathrm{a}}$ & $34.0^{\mathrm{a}}$ & $33.5^{\mathrm{a}}$ & 8.5 & 2.8 & 44.2 & 44.5 \\
\hline
\end{tabular}

The control (0.0) represents untreated plants. The other groups of plants were irradiated with different doses of $\gamma$ - rays. Each value is the mean of three replicates. Different letters indicate significant variation.

TABLE 3. Effect of pre-sowing irradiation treatments on mineral contents of sesame crops

\begin{tabular}{lccccccc}
\hline Treatment Gy & $\mathbf{C a}$ & $\mathbf{C l}$ & $\mathbf{F e}$ & $\mathbf{K}$ & $\mathbf{M g}$ & $\mathbf{N a}$ & $\mathbf{P}$ \\
\hline 0.0 & $27.2^{\mathrm{a}}$ & $0.9^{\mathrm{c}}$ & $0.96^{\mathrm{d}}$ & $24.0^{\mathrm{c}}$ & $14.8^{\mathrm{c}}$ & $1.9^{\mathrm{b}}$ & $30.4^{\mathrm{d}}$ \\
30 & $17.7^{\mathrm{d}}$ & $1.7^{\mathrm{a}}$ & $2.9^{\mathrm{a}}$ & $27.5^{\mathrm{b}}$ & $14.9^{\mathrm{bc}}$ & $1.6^{\mathrm{bc}}$ & $33.9^{\mathrm{b}}$ \\
60 & $24.4^{\mathrm{b}}$ & $0.91^{\mathrm{c}}$ & $1.5^{\mathrm{b}}$ & $24.1^{\mathrm{c}}$ & $15.3^{\mathrm{a}}$ & $2.6^{\mathrm{a}}$ & $31.2^{\mathrm{c}}$ \\
90 & $18.6^{\mathrm{c}}$ & $1.4^{\mathrm{b}}$ & $1.3^{\mathrm{c}}$ & $28.0^{\mathrm{a}}$ & $15.1^{\mathrm{b}}$ & $1.4^{\mathrm{c}}$ & $34.4^{\mathrm{a}}$ \\
\hline
\end{tabular}

The control (0.0) represents untreated plants. The other groups of plants were irradiated with different doses of $\gamma$ - rays. Each value is the mean of three replicates. Different letters indicate significant variation.

Leucine $\left(67.2 \mathrm{mg} \cdot \mathrm{g}^{-1}\right)$ was the prominent amino acid in sesame followed by arginine $\left(37.2 \mathrm{mg} \cdot \mathrm{g}^{-1}\right)$, glutamic acid $\left(24 \mathrm{mg} \cdot \mathrm{g}^{-1}\right)$ and aspartic $\left(18.0 \mathrm{mg} \cdot \mathrm{g}^{-1}\right)$ in $30 \mathrm{~Gy}$ sesame plants. The constant value of proline in all irradiated treatments $\left(2.4 \mathrm{mg}^{-1}\right)$ was less than the control value $\left(3.6 \mathrm{mg} \cdot \mathrm{g}^{-1}\right)$ and considered as a reference for mild doses used for sesame because proline increases under stress with high doses. But, nine amino acids remained constant in the higher dose used (90 Gy) while the rest decreased except for cystine, which increased by $2.04 \%$ (from $8.4 \mathrm{mg} \cdot \mathrm{g}^{-1}$ in the control to $9.6 \mathrm{mg} \cdot \mathrm{g}^{-1}$ ). The total of amino acids revealed that $30 \mathrm{~Gy}$ had the highest value (350.4) followed by $60 \mathrm{~Gy}$ (285.6).

\section{DISCUSSION}

Gamma radiation is a potent group of mutagens widely used to create additional variability for crop improvement. Low doses of $\gamma$-irradiation may increase the enzymatic activity and stimulate the embryo which in turn causes an increase in the rate of cell division and affects vegetative growth and causes thickening of the stem and increases plant dry weight, number and weight of capsules. Similar findings were cited by other researchers. Sjodin (1962) and Moussa and abdul Jaleel (2010) studied the effect of radiation doses $(0.0-150 \mathrm{~Gy})$ on Trigonellafoenum-graecum L. and noticed that 150 Gy gamma irradiation dose increased dry weight values. Radiation causes oxidative injury by acceleration of free radical generation in living systems. The primary damage induced by ionizing radiation is modified in the enzymatic repair processes (Alikamanoglu et al., 2007). Lower doses of $\gamma$-irradiation (0-200 Gy) might facilitate better germination, growth and development when all the barriers are overcome, including dormancy in Terminalia arjuna (Roxb), Akshatha et al. (2013). Gamma irradiation at the levels of 30 or $60 \mathrm{~Gy}$ affected the stem diameter. Similar findings were reported by El-Khateeb et al. (2007), who stated that lower doses of gamma irradiation affected and changed shoot chemical and anatomical structure in Melissa plantlets. The increase in 
TABLE 4. Effect of pre-sowing irradiation treatment on amino acid contents of sesame crop

\begin{tabular}{|c|c|c|c|c|}
\hline \multirow[b]{2}{*}{ Amino acids $\left(\mathrm{mg} \cdot \mathrm{g}^{-1}\right)$} & \multicolumn{4}{|c|}{$\gamma$ - ray $\mathbf{G y}$} \\
\hline & Control & 30 & 60 & 90 \\
\hline Aspartic & 13.2 & 18.0 & 16.8 & 13.2 \\
\hline Threonine & 10.8 & 16.8 & 13.2 & 10.8 \\
\hline Serine & 12.0 & 16.8 & 14.4 & 10.8 \\
\hline Glutamic & 18.0 & 24.0 & 21.6 & 18.0 \\
\hline Proline & 3.6 & 2.4 & 2.4 & 2.4 \\
\hline Glycine & 9.6 & 12.0 & 10.8 & 8.4 \\
\hline Alanine & 7.2 & 10.8 & 8.4 & 7.2 \\
\hline Cystine & 8.4 & 13.2 & 10.8 & 9.6 \\
\hline Valine & 12.0 & 18.0 & 14.4 & 10.8 \\
\hline Methionine & 13.2 & 18.0 & 14.4 & 10.8 \\
\hline Isoleucine & 12.0 & 18.0 & 13.2 & 12.0 \\
\hline Leucine & 50.4 & 67.2 & 51.6 & 40.8 \\
\hline Tryrosine & 10.8 & 16.8 & 12.0 & 9.6 \\
\hline Phenylalanine & 15.6 & 21.6 & 18.0 & 15.6 \\
\hline Histidine & 15.6 & 21.6 & 16.8 & 15.6 \\
\hline Lysine & 13.2 & 18.0 & 15.6 & 13.2 \\
\hline Arginine & 28.8 & 37.2 & 31.2 & 28.8 \\
\hline Total $\left(\mathrm{mg} \cdot \mathrm{g}^{-1}\right)$ & 254.4 & 350.4 & 285.6 & 237.6 \\
\hline
\end{tabular}

oil percentages may be attributed to the difference in moisture content in sesame seeds. Many researchers noticed significant differences in the percentages of oil in two Nigerian sesame cultivars irradiated with $4,8,12$ and $16 \mu \mathrm{Sv}$ doses of fast neutron irradiation (Falusi et al., 2013) and in Capsicum annum (Falusi et al., 2012a; Falusi et al., 2012b). Sesame seeds contain up to $55 \%$ oil which is rich in linoleic and oleic acids; it has a cholesterol-lowering effect (Martinchik, 2011). The same trends were seen concerning the shortage in oil viscosity upon using gamma irradiation 5, 10, $15 \mathrm{k}$ Gy (Swailam and Hammad, 2012; Swailam, 2009).

For optimal growth and development, 17 essential elements are required by crop plants. If any element is lacking in the soil or not adequately balanced with other nutrients, growth suppression or even complete inhibition may result (Mengel et al., 2001). The minerals investigated in sesame plants are shown in Table 3. Phosphorus, calcium and potassium represent the major minerals in the control plants. From the nutritional point of view, the available nutrient status was significantly improved $(\mathrm{Fe}, \mathrm{K}, \mathrm{Mg}, \mathrm{P})$ in irradiated samples. Magnesium contents were generally in accordance with previous publications. Beside the familiar function of $\mathrm{Mg}^{2+}$ as the central ion in the chlorophyll molecule, it is essential because it combines with ATP (thereby allowing ATP to function in many reactions) and because it activates many enzymes needed in photosynthesis, respiration and formation of DNA and RNA (Salisbury and Ross, 1992).

Except for proline, the increase in amino acid values in irradiated samples above the control ones was similar to those reported for black Cumin (Al-Jassir, 1992), sesame (Swailam, 2009) and mung bean (Hussein, 2010). Pathirana and Subasinghe, (1993) added that the seeds are highly resistant to irradiation.

\section{CONCLUSIONS}

Gamma rays (30 and $60 \mathrm{~Gy}$ ) increased sesame yield, oil fractions, mineral contents and amino acids. While unsaturated fatty acids were increased, the saturated ones decreased. The amount of unsaturated fatty acid (18:1, omega 9) was increased by $10.5 \%$ at $30 \mathrm{~Gy}$ dose followed by $60 \mathrm{~Gy}(1.1 \%)$. The high levels of unsaturated fatty acids increase the quality of the oil for human consumption. Therefore, further investigation on a broad scale is required of radiation doses and intensities to determine the best dose for oil quantity and quality.

\section{ACKNOWLEDGMENTS}

We wish to thank the National Center for Radiation Research and Technology for help needed to accomplish this search.

\section{REFERENCES}

Akshatha Chandrasekhar KR, Somashekarappa HM, Souframanien J. 2013. Effect of gamma irradiation on germination, growth, and biochemical parameters of Terminalia arjuna (Roxb) Radiation Protect. Environment 36, 38-44. http://dx.doi.org/10.4103/0972-0464.121826.

Alikamanoglu S, Yaycili O, Atak C, Rzakoulieva A. 2007. Effect of magnetic field and gamma radiation on Paulowiniatomentosa tissue culture. Biotechnol. Biotechnol. Eq. 21, 49-53. http://dx.doi.org/10.1080/13102818.2007.10817412.

Al-Jassir MS.1992. Chemical composition and micro flora of black cumin (Nigella sativa L.) seeds growing in Saudi Arabia. Food Chem. 45, 239-242. http://dx.doi.org/10.1016/ 0308-8146(92)90153-S.

Al-Yemeni MN, Hussain AM, Basahy AY. 2000. Mineral composition of some sesame seeds (Sesamumindicum L.) grown in the Gizan area of Saudi Arabia. Phyton. 67, 121-125.

AACC 1993. American Association of Cereal Chemistry. Approved method 44-15A (Moisture-air oven method). The Association of Cereal Chemistry, St Paul

AOAC 1984. Official methods of analysis.14th ed. Association of Official Analytical Chemists. Arlington, VA.

AOAC 1990. Official methods of analysis. Association of Official Analytical Chemists.15th ed, Washington, DC, USA

Ashri A. 2007. Sesame (Sesamumindicum L.). In: Singh RJ (ed) Genetics resources chromosome Engineering and crop improvement, Oilseed crop. 4, 231-289, CRC Press, Boca Raton, FL, USA.

Baxter JH. 1996. Amino Acids. In: "Handbook of Food Analysis" vol. 1 Leo M.L. Nollet Eds. Marcel Dekker. Inc., New York, 197-228.

Bedigian D. 2000. Sesame. In: The Cambridge World History of Food, K.F Kiple and Orenelas-Kiple (Eds.). Cambridge University Press, New York, 411-412.

Duncan DB. 1955. Multiple ranges and multiple F. test. Biometrics, 11, 1-24. http://dx.doi.org/10.2307/3001478. 
El-Khateeb MA, Sharabash MT, El-Sharnouby ME, Hamideldin N, Nasr AA, Sayed RI. 2007. Effect of sterilization and gamma irradiation on growth, chemical and anatomical composition of Melissa plant through tissue culture. Isotope RAD. Res. 39, 575-582.

Falusi OA, Liman MM, Lateef AA, Adamu GA, Daudu YO Abejide DR. 2013. Effect of fast neutron irradiation on yield parameters of two Nigerian sesame cultivars. Academic $J$. Biotech. 1, 105-108.

Falusi OA, Daudu OY, Teixeira da Silva JA. 2012a. Effects of fast neutron irradiation on agronomic Traits of Nigerian pepper (Capsicum annum L.). Eur. J. Horticult. Sci. 77, 41-45.

Falusi OA, Daudu OY, Texetra da Silva JA. 2012b. Effect of exposure time of fast neutron irradiation on growth and yield parameters of Capsicum annum and Capsicum frutescens. Afri. J. Plant Sci. 6, 251-255. http://dx.doi.org/10.5897/ AJPS.

Hamilton S, Hamilton R, Sewell PA. 1992. Extraction of lipids and derivative formation: In "Lipid Analysis a practical approach" Edited by S. Hamilton and R. Hamilton (Eds.). IRL PRESS at Oxford Uni. Press. Oxford New York Tokyo.oclc/26094728.

Hussein OS. 2010. Effect of ascorbic acid and or sodium chloride on irradiated mungbean seeds. Arab J. Nucl. Sci. Applied 43, 281-288.

Kim JH, Beak MH, Chnug BY, Wi SG, Kim JS. 2004. Alternation in the photosynthic pigments and antioxidant machineries of red pepper (Capsicum annum L.) seedling from gamma irradiated seeds. J. Plant Biol. 47, 314-321.

Martinchik AN. 2011. Nutritional value of sesame seeds. Vopr. Pitan. 80, 41-43.

Mengel K, Kirkby EA, Kosegarten H, Appel T. 2001. Principles of plant nutrition Kluwer Academic Publisher, Dordrecht,
The Netherlands (5th ed). ISBN-13-10:978-1402000089. http://dx.doi.org/10.1007/978-94-010-1009-2.

Moussa HR, abdul Jaleel C. 2010. Physiological Effects of Glycinebetaine on Gamma-Irradiated Fenugreek Plants (Trigonellafoenum-graecum L.). Internat. J. Vegetable Sci. 17, 60-74 http://dx.doi.org/10.1080/19315260.2010.509124.

Pathirana R, Subasinghe S. 1993. Response of two Sesame cultivars to seed irradiation withgamma rays. J. Nat. Sci. Coun Sri Lanka. 21, 183-188.

Rahimi MM, Bahrani A. 2011. Influence of gamma irradiation on some physiologicalcharacteristics and grain protein in wheat (Triticumaestivium L.). World Appl. Sci. J. 15, 654-659.

Salisbury FB, Ross W. 1992. Plant Physiology. 2nd ed. Mineral Nutrition Chap. 6, 116-135 Wadsworth Publishing Company, Belmont California.

Singh B, Datta PS. 2010. Gamma irradiation to improve plant vigor, grain development, and yield attributes of wheat. Rad. Physic. Chem. 79, 139-143.

Sjodin J. 1962. Some observation in X1 and X2 of Viciafaba L. after treatment with differentmutagenes. Hereditas $\mathbf{4 8}$, 565-586.

Swailam MH, Hammad AA. 2012. Sterilization of spices and dried vegetable by gamma radiation and its effect on their amino acids content and viscosity. Az. J. Microbiol. 56, 281.

Swailam MH. 2009. Quality characteristics of irradiated sasame seeds during storage. J. Rad. Sci. Applic. 22, 323-342.

Ustimenko-Bakumovsky GV. 1980. Sesame, In: Plant growing in the tropics and subtropics, 272-279. Mir Publishers, Moscow.

Wi SG, Chung BY, Kim JH, Baek MH, Yang DH, Lee JW, Kim JS. 2005. Ultra structural changes of cell organelles in Arabidopsis stem after gamma irradiation. J. Plant Biol. 48, 195-200. http://dx.doi.org/10.1007/BF03030408. 